УДК 371.3:372.881.111.1

DOI:

Наталія Мельник, викладач англійської та німецькой мов

Методична комісія філологічних дисииплін

Вище художнє професійне училище №3, м. Івано-Франківськ

\title{
РОЛЬОВІ ІГРИ ЯК ПРОДУКТИВНО-ІНТЕРАКТИВНА ФОРМА НАВЧАННЯ АНГЛІЙСЬКОЇ ТА НІМЕЦЬКОЇ МОВ
}

У статті розкрито теоретичні підходи до розуміння концепту “гейміфікації” та переваги його застосування у рамках освітньо-педагогічної діяльності. Встановлено, щзо основною проблематикою, зякою стикаються викладачі в цифрову епоху, є інтенсифікачія інтересу здобувачів освіти до навчання та, зокрема, опанування іноземних мов. Окреслено рольове призначення та напрями інтеграції в навчальний процес гейміфікованих технологій. Подано класифікацію ігор, які можуть застосовуватися у ході вивчення будьяких дисииплін, а також рівні гейміфікації завдань. Розкрито принциии та підходи до формування контенту навчальних ігор. Визначено иільове призначення пізнавально-розважальних ігор та Інтернет-ресурси, що стануть корисними при підготовці до проведення заняття у формі гри. Наведено приклади того, як перенесення елементів гри в неігрове середовище викладання іноземної мови здатне підвищити успішність навчання учнів училища.

Ключові слова: гейміфікачія; рольова гра; інтерактивне навчання; лідерборд; прогрес; комунікативні здібності; ситуативні ролі (кейси); фідбек.

Jim. 9.

Nataliia Melnyk, Lecturer of English and German Languages, Methodical Department of Philological Discipline,

Higher Art Vocational School No. 3, Ivano-Frankivsk

\section{ROLE GAMES AS A PRODUCTIVE-INTERACTIVE FORM OF ENGLISH AND GERMAN LANGUAGES}

The article reveals theoretical approaches to understanding the concept of "gamification" and the benefits of its application in educational and pedagogical activities. It is established that the main problem faced by teachers in the digital age is the intensification of the interest of educators in learning and, in particular, the acquisition of foreign languages. The role purpose and directions of integration into the educational process of gamified technologies are outlined; the classification of games that can be used in any discipline, as well as the levels of gamification of tasks. The principles and approaches to the formation of the content of educational games are revealed. The purposes of cognitive and entertaining games and Internet resources that will be useful in preparation for the lesson-game are determined. Examples are given of how the transfer of elements of the game into a non-game environment of foreign language teaching can improve the learning success of teaching college students.

It is emphasized that role-playing games in foreign language classes (including English and German) are aimed at developing students' communicative competencies. At the same time, it is proposed to modify the game formats and the degree of students' involvement, depending on the ultimate goal of the lesson and the specifics of the processed material. Examples and topics of interviews used in English lessons are given; principles of organizing games in the format of "Business Contacts" and "Scientific Conference". An overview of German filmography and examples of pictures that should be used for communication in roles is offered. We focus on the functionality of individual Google services. According to the results, role-playing, as part of gamification, is the driving force of modern teaching methods.

Keywords: gamification; role play; interactive learning; leaderboard; progress; communicative abilities;ituational roles (cases); feedback.

A ктуальність теми. В умовах розвитку дистанційної освіти, перенасиченост віртуального простору (мережі Інтернет) різного роду відомостями, перед сучасними викладачами постає проблематика активізації інтересу здобувачів освіти щодо освітнього процесу. Особливо, це стосується опанування учнями профільних і непрофільних спеціальностей іноземних мов та отримання відповідних навичок, які можна застосовувати на практиці. У світлі зазначеного, об'єктивною постає потреба пошуку методик викладання, що є найбільш ефективними для цільової аудиторії, виходячи з іiі інтересів та захоплень. Як правило, у такому випадку викладачі часто вдаються до застосування методики скрайбінгу, коучингу, ментальних карт. Безперечно, перелічені способи активізації уваги та пізнавального інтересу учнів виправдовують 


\section{РОЛЬОВІ ГГРИ ЯК ПРОДУКТИВНО-ІНТЕРАКТИВНА ФОРМА НАВЧАННЯ АНГЛІЙСЬКОЇ ТА НІМЕЦЬКОӤ МОВ}

свою дієвість, проте ми не можемо назвати їх універсальними, тобто такими, що прийнятні для застосування на кожному занятті, чого не можна сказати про гейміфікацію. Відповідно, в світлі інтенсивних освітньо-наукових змін, цікаво дослідити способи використання окремих практик гейміфікації, що стануть корисними у викладацькій практиці іноземних мов.

Зазначене питання вже було предметом наукових пошуків таких вчених, як Н. Бойко [1], А. Горген [2], О. Кобзар та Н. Лєшньова [4], К. Косенко й Ю. Томіліна [5], Н. Кравець [6], проте вони досліджували це питання, як правило, через призму інших дисциплін. Зі свого боку метою нашого дослідження є окреслення продуктивноінтерактивних рольових ігор, як однієї із форм гейміфікації, в процесі їх застосування на заняттях із англійської та німецької мов.

Виклад основного матеріалу. Концепт “гейміфікація" прийнято трактувати як застосування практик і методик у неігровому контексті, заснованих на принципі залученості учасників до розв'язання змодельованих проблем. В останній роки гейміфікація позиціонується як must do, освітній тренд, широко застосований у викладацькій практиці, адже він підходить для молодшого та старшого покоління. Як методика, вона акумулює у собі низку психологічних прийомів, заснованих на людських інстинктах - змагальності, співробітництві, азарті, прагненні перемагати й транслювати свої лідерські якості [5, 130]. Означений спосіб покликаний викорінити відчуття рутини від навчання, яка сама собою знижує мотивацію та розсіює увагу. Як правило, гейміфікація застосовується при вивченні матеріалу із точних та природничих наук. Відповідно, виокремлюють три основні рівні цього процесу:

- гра зі встановленням рейтингу (лідерборд), застосування системи оцінювання, що вказує на результати і досягнення здобувачів освіти (команди);

- гра, заснована на певному сюжеті (історії). Їй властива динамічність, завдання систематизуються залежно від рівня їх складності. Як правило, часто застосовуються інтерактивні освітні відеоролики, візуальні підказки для правильного розв'язання проблемного питання, техніки “мозкового штурму”, ігрового проєктування, лекція-диспут, кейс-стаді та інші способи командної роботи;

- розробка повноцінної гри, адаптованої під когнітивні властивості, вміння та навички аудиторії (iii окремої частини) із акцентами на тій частині матеріалу, яка складніше засвоюється учнями.

Водночас, слід зауважити, що методика застосування бейджів, лідербордів та оцінювання за результатами гри сильно загострює конкуренцію. Тобто, недоцільно фокусувати всі гейміфіковані заняття саме на кінцевому результаті, а навпаки - створювати умови для відчуття прогресу і задоволення у процесі гри. Якщо гра має прикладний характер, то спрямовує ігрові патерни для розв'язання життєвих проблематик. Для цього, при формуванні контенту та основних елементів гри, важливо врахувати низку рекомендацій, що зробить їі більш привабливою. Передовсім зміст кожної гри має бути закладена певна таємниця, що здатна підсилити азарт. Це може бути як приз у “чорному ящику” (форма винагороди лідеру), так і суперзавдання, яке забажають розсекретити учасники гри. Логічно, що за таких умов важливим фактором $є$ присутність відчуття ризику, що активізує когнітивні функції та змушує учасників транслювати здібності. Досягнути бажаного ефекту на виключно в умовах невизначеності, коли учні не знають наперед продуманого сценарію або відповіді на конкретні завдання, тим самим тримаючи аудиторію в напрузі. Важливо знайти золоту середину: щоб гра не була занадто простою чи складною для іiї учасників, позаяк у першому випадку вона буде нецікавою та не нестиме для реципієнтів жодного смислового (повчального) навантаження, не реалізуватиметься евристична функція пізнання; а в другому здобувачі освіти опускатимуть руки від нерозуміння ймовірних шляхів вирішення кейсу. Емоиійна складова та видимість прогресу спонукають учасників рухатись уперед, роблять його захопливим і незабутнім [10].

Насамкінець, влучно зауважує Н. Кравець, що 3-поміж перелічених ознак найважливіше місце відводиться наявності оперативного зворотнього зв'язку від контрагента $[6,118]$.

Пізнавально-розважальні ігри можна класифікувати на декілька груп. По-перше, мова йде про підготовчі ігри, основною метою яких $\epsilon$ формування мовних навичок. Сюди входить така підгрупа, як граматичні ігри, що має на меті навчити використовувати на практиці мовні зразки, котрі містять певні граматичні проблеми, створюючи тим самим звичну ситуацію спілкування, що сприятиме розвитку творчої активності. Значними тут $є$ і лексичні, які тренують вживання лексики та розвивають мовленнєву діяльність і реакцію учнів. До другої належать творчі ігри, завдяки яким можливий розвиток креативних здібностей. Тут важливе місце займають драматичні, ділові та рольові ігри, оскільки вивчивши певний матеріал, учень 


\section{РОЛЬОВІ ІГРИ ЯК ПРОДУКТИВНО-ІНТЕРАКТИВНА ФОРМА НАВЧАННЯ АНГЛІЙСЬКОЇ ТА НІМЕЦЬКОЇ МОВ}

найчастіше не здатний використовувати його у життєвих ситуаціях. Застосування згаданої групи підштовхує його використовувати накопичені знання, самостійно обирати оптимальне рішення у складній ситуації.

В умовах розвитку дистанційного навчання, на допомогу викладачу при підготовці до проведення заняття-гри прийдуть такі Інтернет-ресурси і додатки, як:

Kahoo - один із найбільш популярних сервісів для створення тестів, вікторин, головоломок, завдань для індивідуальної і групової роботи. Технічний функціонал онлайн ресурсу дозволяє використовувати контент, що розміщений на сайті, або ж генерувати власний, виходячи із тематики заняття. Базова підписка - безкоштовна; доступ до преміальних зображень, функція “відкритих запитань”, залучення до онлайн-гри до 100 учасників - ці та інші переваги доступні в платній версії;

Quizlet Live усуває недоліки, що характерні для попередньої платформи та дає змогу одночасно брати участь у грі більше шести учасникам. Більше того, ресурс розподілено за навчальними предметами. Тут наявні модулі 3 англійської та німецької мов. 3 нашої позиції, при формуванні англомовного контенту гри доцільно застосовувати широкі можливості, які надає Quizlet Live. Як експеримент (форми підсумкового контролю), перед студентами можна поставити завдання самостійно розробити рольову гру та викласти правила іноземною мовою, базуючись на матеріалі, що запропонований на платформі Quizlet Live.

Quizziz - англомовний ресурс із готовими вікторинами, розподіленими за тематиками: English and language arts, social studies, computer science and skills, mathematics, creative arts. Перевагою вебсторінки $\epsilon$ те, що вона синхронізується із Google Classroom.

Водночас гейміфікація навчання не завжди виправдовує себе через низку складнощів та бар'єрів. 3 організаційної точки зору, перше з чим стикаються модератори, - це брак конкретики. Мета заняття має кореспондуватися із креативним підходом до його втілення. Мало досліджена аудиторія - не досить вдале рішення для експериментів, адже інтеграція навчання ігрових елементів вимагає чіткого розуміння цінностей та установок групи. Більше того, для кожної вікової групи мають застосовуватися різні методи інтеракції, візуально-звуковий та дизайн-супровід. Варто усвідомити єдине правило: гра не має заміщувати фокусацію на навчанні, вона позиціонується лише як спосіб досягнення поставленої цілі.
Так, 3-поміж відомих моделей поведінки, які практикуються у ході гейміфікації навчання, виділяють співпрацю, змагання, розвідування. Кожен із перелічених елементів може бути закладений в основу рольової гри. Базуючись на позиції Ю. Холмакова, можна зауважити, що рольову гру в освітній діяльності прийнято розуміти як інтерактивний вид навчання із попередньо змодельованою ситуацією (кейсом), де для кожного учня виділена конкретна роль. 3поміж іншого, вона дає змогу сформувати власну думку про загальну обстановку в колективі, сприяє формуванню навчального співробітництва, розширює асоціативну базу кожного індивіда $[9$, 533-534].

Л. Карамушка зазначає, що рольові ігри, 3 точки зору психолого-педагогічної науки, можна поділяти на дві групи: власне навчально-рольові (мета - провести глибинний аналіз проблеми) та ділові ігри (імітація реальних ситуацій, що передбачає вибір практичних рішень) [3, 788].

3 позиції викладання іноземних мов, застосування рольових ігор виправдовує себе за рахунок розвитку всіх видів мовленнєвої діяльності учня. Питома вага припадає на діалогічну комунікацію, проте часто трапляються випадки, коли учасник має у форматі монологу донести до аудиторії власну позицію, аргументувати та переконати реципієнтів свого спічу. Модель участі викладача може бути конвергентною та дивергентною. При першій ставиться проблема, ролі даються в деталях, увага концентрується на вирішенні проблеми, при другій дається ситуація без детальних ролей та послідовності, увага концентрується на діяльності учасників [2].

Найпростішою формою рольової гри $\epsilon$ інтерв'ю. Викладач задає тематику діалогу, самостійно або на розсуд учасників визначає ролі та оцінює змістове наповнення реплік, їх коректність. У процесі до діалогу можуть долучатися інші учасники за умови дотримання наперед визначених ролей. Теми мають бути незаангажовані, збуджувати думку молоді та стимулювати мислити масштабно. Так, учням перших курсів доцільно запропонувати обговорити із опонентом одну із поданих тем:

Super Star: the way you became famous,

Living in London (another city): the advantages and disadvantages of living in a big city;

Role Model: who is the most important person for you? Why?

Healthy or Junk food: your recommendations.

Для учнів старших курсів навпаки 


\section{РОЛЬОВІ ІГРИ ЯК ПРОДУКТИВНО-ІНТЕРАКТИВНА ФОРМА НАВЧАННЯ АНГЛІЙСЬКОЇ ТА НІМЕЦЬКОЇ МОВ}

рекомендовано звужувати ситуативні умови, щоб вони генерували синонімічні та антонімічні ряди, фраземи в процесі мовлення. Як варіант, пропонуємо наступну гру:

Role I. You see an advertisement in a newspaper. Phone up and find out more about the flat. [Make a note of things you want to ask about before you phone]. If the flat sounds suitable, arrange to go round and see it.

Role II. You have a flat to rent. You put an advertisement in a newspaper. Someone phones up about the flat. Answer their questions. [Think first what they might ask and have the answer ready]. If the person is interested arrange for him / her to come and have a look at it.

Role I. You work in the overseas department Bolton brothers. You're on a business trip. You're in the hotel lounge, writing reports. You're tired, you want peace and quiet. You don't want to talk to anyone. You do not want to go out tonight, but finally agree to it. Be polite, but negative.

Role II. You're in your hotel lounge. You want to watch TV. If you can't do that you might as well chat to someone. You think you recognize the other person in the room. You have recently visited the firm of Bolton brothers. It might be there that you met. Try and strike up a conversation, and invite the other person out tonight. Try to persuade him / her [8].

Ефективними будуть рольові ігри формату "Business Contacts" та "Scientific Conference" [4, 128]. У першому випадку моделюємо ситуацію, максимально наближену до професійної діяльності учня: Hal went to the bank for a loan, but with his business struggling, he didn't qualify. What happened? Тобто формується ситуації, за якої з'являються мінімум два учасники гри: працівник банку та клієнт, належна комунікація яких передбачає оперування відповідною бізнеслексикою. У центрі "Scientific Conference" має фігурувати гостра, актуальна проблематика, вирішення якої має здійснюватися комплексно. Рольова гра проводиться між ведучим конференції, доповідачем та аудиторією, яка задає по 1-2 питань, згідно з тематикою виступу. Для учнів такої спеціальності, як, до прикладу, декоративно-прикладне мистецтво, варто запропонувати провести мінібатл "Design, the art of organizing the world of things".

Орієнтовний кейс: на основі конкурсу проходить відбір до фірми, в якій ви мрієте працювати. Комісія обирає найліпший проєкт, відповідно, конкурсанту важливо його продемонструвати в найкращому світлі та зазначити, чому саме його робота має бути визнана найкращою з-поміж представлених.
Учнів розбивають по двоє, беруть за основу проєкти (landscaping, interior design, classic interior in modern design), які попередньо розроблені ними на заняттях із профільних дисциплін, описують іноземною мовою переваги і ті аспекти, які можуть бути вдосконалені у роботі. Потім перед колегами кожен демонструє власну роботу, в тому числі порівнюючи із проектом свого опонента.

Якщо виникає потреба у відпрацюванні частин мови - доречно вдатися до альтернативи. Для закріплення просторових прийменників та іншої лексики можна запропонувати учням рольові ігри 3 картами. Учасникам необхідно описати маршрут за схемою: знайти шлях до відомих пам'яток чи інших туристичних об'єктів рідного міста. Можна запропонувати їм розповісти про улюблені локації у населеному пункті, відчути себе в ролі гіда.

Не менш цікавий і ефективний спосіб, який доцільно практикувати як в режимі online, так $\mathrm{i}$ offline, $є$ спільний перегляд фільмів (окремих епізодів) мовою оригіналу. До прикладу, учням із рівнем німецької мови А2 - В1можна запропонувати переглянути вирізки із німецької класики "Lola rennt". Викладач, оцінивши здібності аудиторії, самостійно визначає потребу у субтитрах, або ж покладається на слухову пам'ять учнів. Картина допоможе не лише опанувати правила коректної вимови, але й ознайомить із специфічною лексикою та розвине у здобувачів освіти хист звертати увагу на деталі. Після прослуховування діалогів із фільму, учням пропонується відтворити їх в аудиторії, максимально передаючи інтонацію та емоції героїв. Для тих, хто полюбляє переглядати серіали, варто звернути увагу на міні-ролики (“Јојо sucht das Glück", "Mein Weg nach Deutschland”), які чудово розширять повсякденну лексику та детальніше познайомлять із культурою німців, цікаві факти про життя в країні. Роль викладача за таких умов зводиться до консультанта: він пояснює сенс незрозумілих фраз, розповідає передісторію фільму (історичні події на яких він базується); тлумачить сакральний зміст картини тощо.

Pесурси Deutsch.info, Deutsche Welle, Deutsch für Dich стануть в нагоді при пошуку необхідних навчальних матеріалів, що буде корисним при формуванні структури і теми рольової гри.

Застосування командних та рольових ігор допустиме при роботі із хмарними технологіями. До прикладу, online-сервіс Classtime робить основний акцент на співпраці здобувачів освіти та ïx інтерактивній взаємодії. Навчальні платформи 


\section{РОЛЬОВІ ІГРИ ЯК ПРОДУКТИВНО-ІНТЕРАКТИВНА ФОРМА НАВЧАННЯ АНГЛИЙСЬКОЇ ТА НІМЕЦЬКОЇ МОВ}

Moodle i Google Classroom дозволяють грати у рольову гру "Eine Karte - ein Gespräch". Передовсім потрібно створити різнокольорові картки, розподілити учасників на групи по $3-5$ осіб та визначитись із капітаном команди. Потім команди методом жеребкування визначають право першого ходу і проставляють хрестики нулики на розграфленому віртуальному аркуші. Результат кінцевого етапу гри визначає флешкартка, на якій закінчиться хід гри. Далі ця картка залишається у команді, яка виграла партію. Вона ж розпочинає гру в наступному етапі. Таким чином, учні грають до того моменту, допоки всі флеш-карти не будуть розподілені між командами (кількість 4x4). Одна карта із залишку дає право вибору теми для обговорення (власна або із запропонованих у картці) [7, 51-52]. До прикладу, орієнтовні тематики: "Globalisierung und Familienleben", "Mein Alltag als Volontärin", "Musik, die mir gefällt", "Meine Wohnung".

Після цього учасники обговорюють між собою теми, що містяться на картках, і висловлюють міркування стосовно предмета обговорення. Викладач слідкує, щоб всі гравці долучалися до дискусії, адже саме такий спосіб вони зможуть виховати повагу до позиції опонента, вміння слухати та знаходити компроміси у певних ситуаціях.

Висновок. Рольова гра навчає бути чутливим до використання іноземної мови та швидко адаптуватися до комунікації іноземною мовою. Хорошим співрозмовником $\epsilon$ часто не той, хто правильно будує синтаксичні конструкції чи підбирає влучні за змістом лексеми, а ті учні, які здатні розпізнати (інтерпретувати) ситуацію, в якій перебувають партнери, врахувати ту інформацію, яка вже відома (із отриманих знань, досвіду) та вибрати лінгвістичні засоби, які будуть найефективнішими в ході спілкування. Практично весь навчальний час у рольовій грі відведено на мовну практику, при цьому не тільки оратор, а й слухач максимально активний, тому що він повинен зрозуміти і запам'ятати репліку партнера, співвіднести iï з ситуацією і дати коректний фідбек. Саме тому цей спосіб гейміфікації навчання ми визначаємо як один із найбільш дієвих при вивченні іноземних мов, зокрема англійської та німецької. Перспективи подальших наукових пошуків вбачаємо у аналізі переваг та недоліків Інтернет-ресурсів для вивчення іноземної мови як позааудиторної форми самоосвіти.

\section{ЛІТЕРАТУРА}

1. Бойко Н.І. Гейміфікація на уроках англійської мови. Житомирщина педагогічна. 2020. № 4 (20). C. $1-7$.

2. Горген А., Люлько М. Рольові ігри як метод навчання іноземної мови. URL: http:// www.rusnauka.com/35_OINBG_2012/Pedagogica/ 5_121861.doc.htm (дата звернення: 08.12.2021)

3. Киливник В. М. Рольова гра як один 3 методів активного навчання студентів іноземній мові. 2012. URL: http://umo.edu.ua/images/content/ nashi_vydanya/stud_almanah/21.pdf(дата звернення: 08.12.2021)

4. Кобзар О.І., Лєшньова Н.О. Рольова гра як засіб підвищення мотивації навчання іноземної мови. Викладання мов у вищих навчальних закладах освіти на сучасному етапі. Міжпредметні зв'язки. Наукові дослідження. Досвід. Пошуки: збірник наукових праць. Харківський національний університет ім. В.Н. Каразіна. Харків, 2008. Вип. 12. С.151-156.

5. Косенко К. О., Томіліна Ю.М. Гейміфікація уроку англійської мови як засіб підвищення ефективності навчання в умовах онлайн навчання. Збірник доповідеи учасників всеукраїнської студентсько-учнівської науково-практичної онлаин конференції. Київ: НУБІП України, 2021. URL:https://www.researchgate.net/publication/ 351358480_Gejmifikacia_uroku_anglijskoi_movi ak zasib pidvisenna efektivnosti navcanna $\mathrm{v}$ umovah onlajn navcanna (дата звернення: 08.12.2021)

6. Кравець Н. С. Метод відбору ігрових механік для використання в навчальних гейміфікованих системах. Вісн. Харків. держ.акад.культури. Серія: Соціальні комунікації. Харків, 2017. Вип. 51. С. 116-125.

7. Мисковець О.І. Комунікативний підхід при вивченні англійської мови (рольові ігри для учнів "Onecard - Onetalk" та "Different or the Same"). 3б. матеріалів III Всеукраїнськоїнауковометодичної Інтернет-конференції. Луцьк: IBB Луцького НТУ, 2020. 288 с.

8. Создание и проведение ролевых игр на английском языке; методические рекомендации для преподавателей: сост. И. Б. Васильева, В. М. Шафоростова; Гос. ун-т. Высшая школа экономики. Москва.: Изд. дом ГУ ВШЭ, 2005. $38 \mathrm{c}$.

9. Холмакова Ю.В. Характеристика рольової гри як ефективного прийому навчання іноземної мови. Молодий вчений. 2016. № 12 (39). С. 533 $-537$.

10. Zvarych I., Kalaur S. M., Prymachenko N. M., Romashchenko I. V., Romanyshyna O. I. Gamification as a Tool for Stimulating the Educational Activity of Students of Higher Educational Institutions of Ukraine and the United States. European Journal of 


\section{РОЛЬОВІ ІГРИ ЯК ПРОДУКТИВНО-ІНТЕРАКТИВНА ФОРМА НАВЧАННЯ АНГЛІЙСЬКОЇ ТА НІМЕЦЬКОЇ МОВ}

Educational Research. 2019. Vol. 8, no. 3. URL: https://doi.org/10.12973/eu-jer.8.3.875 (date of access: 04.01.2022).

\section{REFERENCES}

1. Boiko, N.I. (2020). Heimifikatsiia na urokakh anhliiskoi movy [Gamification in English lessons]. Zhytomyr region is pedagogical, no. 4(20), pp. 17. [in Ukrainian].

2. Horhen, A. \& Liulko, M. Rolovi ihry yak metod navchannia inozemnoi movy [Role-playing games as a method of teaching a foreign language]. Available at: http://www.rusnauka.com/35_OINBG_2012/ Pedagogica/5_121861.doc.htm (Accessed 08 Dec. 2021) [in Ukrainian].

3. Kylyvnyk, V. M. (2012). Rolova hra yak odyn $\mathrm{z}$ metodiv aktyvnoho navchannia studentiv inozemnii movi [Role play as one of the methods of active learning of foreign languages by students]. Available at: http://umo.edu.ua/images/content/nashi_vydanya/ stud_almanah/21.pdf (Accessed 08 Dec. 2021). [in Ukrainian].

4. Kobzar, O.I. \& Leshneva, N.O. (2008). Rolova hra yak zasib pidvyshchennia motyvatsii navchannia inozemnoi movy [Role play as a means of increasing the motivation to learn a foreign language]. Mizhpredmetni zviazky. Naukovi doslidzhennia. Dosvid. Poshuky - Teaching languages in higher education at the present stage. Interdisciplinary links. Scientific research. Experience. Search: a collection of scientific papers. Kharkiv National University named after V.N. Karazina. Kharkiv, vol.12, pp. 151156. [in Ukrainian].

5. Kosenko, K. O. \& Tomilina, Yu.M. (2021). Heimifikatsiia uroku anhliiskoi movy yak zasib pidvyshchennia efektyvnosti navchannia $v$ umovakh onlain navchannia [Gamification of English lessons as a means of improving the effectiveness of learning in online learning]. Collection of reports of Participants of the All-Ukrainian student-student Scientific-Practical Online Conference. Kyiv. Available at: https://www.researchgate.net/ publication/351358480_ Gejmifikacia_uroku anglijskoi_ movi_ak_zasib_pidvisenna_ efektivnosti_navcanna_v_umovah_onlajn_navcanna [in Ukrainian].

6. Kravets, N. S. (2017). Metod vidboru ihrovykh mekhanik dlia vykorystannia $\mathrm{v}$ navchalnykh heimifikovanykh systemakh [Kravets NS Method of selection of game mechanics for use in educational gamified systems]. Bulletin of Kharkiv. State Academic culture. Series: Social Communications, vol.51, pp.116-125. [in Ukrainian].

7. Myskovets, O.I. (2020). Komunikatyvnyi pidkhid pry vyvchenni anhliiskoi movy (rolovi ihry dlia uchniv "Onecard - Onetalk" ta "Different or the Same") [Communicative approach in learning English (role-playing games for students "Onecard - Onetalk" and "Different or the Same")]. Zb. materialiv III Vseukrainskoinaukovo-metodychnoi Internetkonferentsii - Coll. Proceedings of the III AllUkrainian Scientific-Methodical Internet Conference. Lutsk. [in Ukrainian].

8. Vasilieva, I.B. \& Shaforostova, V.M. (2005). Sozdanie i provedenie rolevyh igr na anglijskom jazyke; metodicheskie rekomendacii dlja prepodavatelej [Creating and conducting role-playing games in English; methodical recommendations for teachers]: comp. Gos. un-t. Higher School of Economics. Moscow. [in Russian].

9. Kholmakova, Yu.V. (2016). Kharakterystyka rolovoi hry yak efektyvnoho pryiomu navchannia inozemnoi movy [Characteristics of role play as an effective method of learning a foreign language]. Young scientist, no. 12(39), pp. 533 - 537. [in Ukrainian].

10. Zvarych, I., Kalaur, S. M., Prymachenko, N. M., Romashchenko, I. V., \& Romanyshyna, O. I. (2019). Gamification as a tool for stimulating the educational activity of students of higher educational institutions of Ukraine and the United States. European Journal of Educational Research, no.8(3), pp. 875-891. https://doi.org/10.12973/eu-jer.8.3.875 [in English].

Стаття надійшла до редакції 19.12.2021

\section{G58080ल2058080}

"Усе своє життя старанно навчайся. Кожен день ставай майстернішим, ніж ти був за день до цього, а на наступний день - майстернішим, ніж сьогодні. Вдосконалення не має кіния".

Ямамото Ұунетомо білософ, письменник

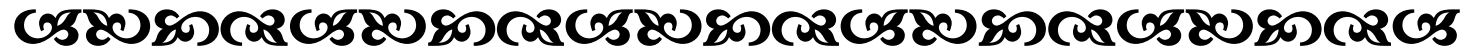

